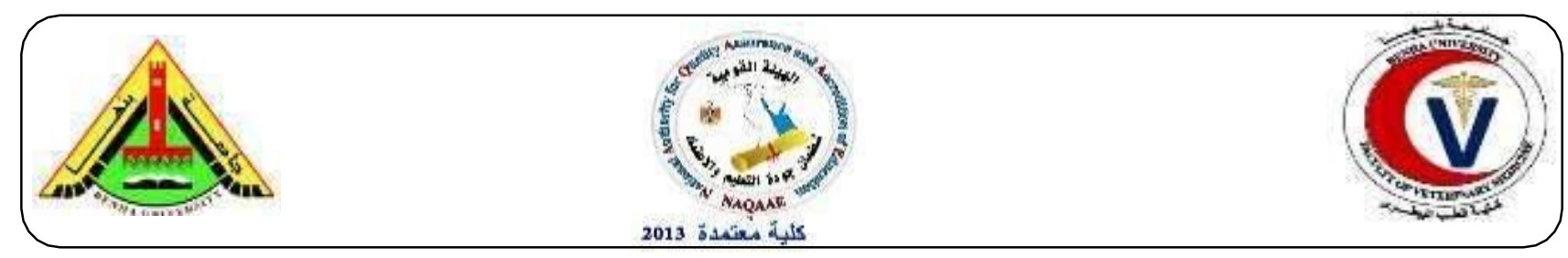

\title{
Epidemiological study on Infectious bursal disease in broiler chicken farms in some Governorates in Delta Egypt
}

\author{
Mohammed A. El-Shorbagy, Ahmed E. Saad, Kamel A. Zyan and Norhan W. Khalil. \\ Avian and Rabbit Diseases Dept., Fac. Vet. Med. Benha Univ.
}

A B STRACT

This study was conducted to estimate the prevalence of IBD in broiler farms from different localities in different Governorates; AlQalubia, AlGharbia, AlMenofia and ALBehera and also to make a further characterization of the obtained strains through nucleotide sequencing then evaluate the pathogenicity of the strain in SPF ECE and commercial broiler chicks. Fifteen out of a total of $32(46.87 \%)$ bursal samples showed 620 bp amplicon size of HVR of VP2 when tested with RTPCR. The nucleotide sequencing classified two strains as vvIBDV and one was similar to classical attenuated vaccines. The vvIBDV strain resulted in $100 \%$ mortality of inoculated embryos with moderate to severe congestion of the body, cranial hemorrhage, congested and greenish liver with necrotic foci. The CAMs showed thickening with petechial hemorrhage. The experimental infection with (IBDV_ EGY 2018/N23) isolate was assessed in vaccinated groups with hot, intermediate and hot + intermediate vaccines and unvaccinated 25 days old Cobb broiler chicks; the c+ve group showed a significant difference in RWBF and cumulative bursal lesion in comparison with c-ve group. It recorded higher MSI than c-ve. All vaccinated groups showed a significant increase in Abs titer when compared with non-vaccinated one and the hot vac. Group recorded the highest titer. They also showed a non-significant difference in RWBF and cumulative bursal lesion score in comparison to c-ve one at ten dPI and lower MSI than c+ve but the hot + intermediate vac. group recorded the lowest lesion score and MSI. This study concluded the reemergence and circulation of vvIBDV despite the intensive vaccination strategies.

Key word: $I B D V, R T / P C R, H V R$ VP2, bursa of Fabricius, Pathogenicity.

(http://www.bvmj.bu.edu.eg)

BVMJ-34 (1), 2018

\section{INTRODUCTION}

The infectious bursal disease is a highly contagious viral disease that is caused by IBDV affecting mainly immature $B$ lymphocyte in the bursa of Fabricius (BF), leading to bursal atrophy in chicks of 3-6 weeks old (Wang et al., 2010). Infectious bursal disease virus (IBDV) is a singleshelled non enveloped with a diameter of 65-
$70 \mathrm{~nm}$, double-stranded bisegmented linear RNA virus that belongs to Birnaviridae family, genus Avibirnavirus (Fauquet et al., 2005). Its genomic RNA consists of segments A that codes to polypeptides cleaved into two structural proteins, VP2 and VP3, a serine protease, VP4 and a nonstructural VP5 while the smaller segment B encodes VP1 (Durairaj 
et al., 2011 ). The VP2 contains the most important region, HVR, where most of the amino acid changes occur. Two distinct serotypes of IBDV have been described; serotype 1 is pathogenic to chickens, whereas serotype two strains are considered nonpathogenic. Since 1989, serotype one has been classified into classical, variant and very virulent strains as a result of amino acid changes in HVR of VP2 (Xu et al., 2011).

Infectious bursal disease is the most important immunosuppressive disease that threatens the poultry production of young chicken (Teshome et al., 2015). Variant and vvIBDVs form the most important antigenic mutants of IBDV that threatens poultry industry causing high economic losses and vaccination failure because of their irreversible immunosuppressive effect on the young chicks (Withers et al., 2005) as well as their ability to break the barrier of maternal immunity and attack the bird in young ages before the time of vaccination (Snyder et al., 1992) in addition to the mortalities that can reach from $50 \%$ and up to $100 \%$ in SPF chicks. Therefore, a rapid and accurate diagnosis of IBDV is a must.

This study aimed to make some light on the current status of IBD through the detection and characterization of IBDV and studying its effect on the broiler chickens.

\section{MATERIALS AND METHODS}

\subsection{Sample Collection.}

The bursae were collected from about 61 IBD suspected broiler flocks from different farms in different Egypt's Governorates from February 2017 till June 2017 with their full historical data, according to OIE, (2016).

\subsection{Virus Identification.}

\subsubsection{Viral RNA Extraction.}

Bursae were prepared for RNA extraction according to OIE, (2016) and viral RNA extraction by Thermo Scientific Gene JET Viral DNA and RNA Purification Kit (K0821).

\subsubsection{Reverse transcriptase-polymerase chain reaction.}

Complementary DNA (cDNA) was synthesized from the extracted RNA, according to HiSenScriptTM RH (-) cDNA Synthesis Kit.

\subsubsection{Polymerase chain reaction.}

A set of primers were designed by Bayliss et al. , (1990 ( and cycling condition of an initial denaturation $95^{\circ} \mathrm{C}$ for 15 min (initial PCR activation); 40 three-step cycles of $94^{\circ} \mathrm{C}$ for the $30 \mathrm{~s}$ (denaturation), $60.8^{\circ} \mathrm{C}$ for $40 \mathrm{~s}$ (annealing) and $72^{\circ} \mathrm{C}$ for $1 \mathrm{~min}$; then $72^{\circ} \mathrm{C}$ for $10 \mathrm{~min}$ (final extension). After amplification, $5 \mu \mathrm{l}$ of PCR products were analyzed by electrophoresis on a $1.5 \%$ agarose gel containing ethidium bromide after amplification (Buitkamp et al., 1991).

\subsubsection{Sequence analysis of VP2 of IBDV.}

PCR products were purified with the QIAquick Gel Extraction Kit (Qiagen); the purified PCR products were sequenced by the Bigdye Terminator V3.1 cycle sequencing kit. (Perkin-Elmer, Foster City, CA) catnumber 4336817 using an Applied Biosystems 3130 genetic analyzer (HITACHI, Japan) and Centrisep (spin column) Kit: cat number CS-901 of 100 reactions were used for purification of the sequence reaction. Data undergo a comparative analysis with other sequences of other strains that published in Genebank using the CLUSTAL W multiple sequence alignment program, version 1.83 of MegAlign module of Lasergene DNAStar software Pairwise (Thompson et al., 1994) and phylogenetic analyses were performed with maximum likelihood, neighbor-joining and maximum parsimony in MEGA6 (Tamura et al., 2013). 


\subsection{Isolation of identified IBDV strains.}

The virus was isolated by three serial passages and titrated in about a total $150 \mathrm{SPF}$ egg from Nile SPF (KoomOshiem, Fayoum, Agriculture Research Center - Ministry of Agriculture), according to OIE, (2016). The titer was calculated according to Atkinson, (1961).

\subsection{Experiment.}

\subsubsection{Commercial broiler chicks.}

A total of 125 one day old Cobb broiler chicks were floor reared under a hygienic condition and provided with commercial broiler ration, water and feed adlibitum. They were divided into five groups.

\subsubsection{Vaccines.}

Two commercial IBDV vaccines; live intermediate Gumboro vaccine: HIPRAGUMBORO CH80, 1000 doses were supplied by LABORATORIOS HIPRA, S.A Spain, batch No: 4R73-1 and Live Hot Gumboro vaccine: HIPRAGUMBORO GM97, 1000 doses was supplied by LABORATORIOS HIPRA, S.A Spain, batch No: 5L84-9.

\subsubsection{Viral strain.}

IBDV_EGY2018/N23 accession No. MH100981 was titrated 1010.5EID50 in ECE by the CAM route then diluted to 105.5 EID50 (Stoute et al., 2013) to be used for the pathogenicity.

\subsubsection{Experimental design.}

The chicks were divided into five groups as follows:- c-ve that was subjected to neither vaccination nor infection, $\mathrm{c}+\mathrm{ve}$ was subjected to infection with 105.5 EID50 of IBDV_EGY2018/N23 isolate via oral route at 25 days old of age, hot vac. group $(\mathrm{H})$ was vaccinated at 12 days old with HIPRAGUMBORO GM97 vaccine, Intermediate vac. group (I) was vaccinated with HIPRAGUMBORO CH80 vaccine at 19 days and hot + Intermediate vac. group $(\mathrm{H}+\mathrm{I})$ was vaccinated at 12 days old with HIPRAGUMBORO GM97 vaccine and HIPRAGUMBORO $\mathrm{CH} 80$ at 19 days old. The vaccination was via ocular route and dose according to manufacture instructions. All the three vaccinated groups were challenged at 25 days old orally with 105.5 EID50 of IBDV_EGY2018/N23, as shown in table 3.

\subsubsection{Data collection before and after the challenge.}

Scarifications were done at 25, 30 and 35 days old (25 days old, 5 and $10 \mathrm{dPI}$ ) for recording different parameters where three chicks/groups were recorded in their live body weight (BW) then sacrificed for recording bursal weight (RWBF) and relative weight of bursa (RWBF) was calculated according to the formula: (BF weight $\mathrm{x} 100$ ) / body weight (Tanimura et al., 1995). Bursal gross changes were recorded.

\subsubsection{Serology.}

Serum samples were collected from 3 chicks/group weekly at 0-7-14-21-25 days old for testing antibody titer by ELISA test, according to Biocheck ELISA KIT.

\subsubsection{Histopathology.}

Bursae were fixed in $10 \%$ buffered formalin for histopathological examination, according to Banchroft et al., (1996) for recording histopathological lesion scoring and mean severity index (Sharma et al., 1989). The cumulative lesion score for bursae was, according to Hussain, (2006).

\subsubsection{Statistical analysis.}

Statistical analysis was performed using the statistical software package SPSS for Windows (version 20.0; SPSS Inc., Chicago, IL, USA). Statistical significance between mean values was set at $\mathrm{P}<0.05$. Differences between groups were analyzed by using OneWay ANOVA and Duncan's multiple comparison Post Hoc tests (Duncan 1955). 


\section{RESULTS}

\subsection{Clinical and postmortem examination of IBD suspected broiler chicken flocks:}

The examined broiler chicken flocks suffered from dehydration and pasty vents from profuse watery diarrhea. At autopsy, petechial hemorrhage was seen on the thigh and breast muscles. Bursae of Fabricius were edematous and enlarged. They contained mucoid to caseous material and also slight to a severe petechial hemorrhage of their mucosa, as shown in figure 1 .

3.2. Molecular prevalence of IBD in suspected chicken flocks:

Fifteen out of 32 bursal samples $(46.87 \%)$ were positive to IBDV as they showed the amplified 620bp fragment on gel electrophoresis, as shown in figure 2 .

\subsection{Nucleotides sequence and phylogenetic} analysis of positively identified IBDV bursal samples:

Three identified strains nucleotides sequence were published on gene bank and had accession numbers (Table 1).

Table (1): The molecular identified strains with their accession No.

\begin{tabular}{ccc}
\hline Strain & Name & accession no. \\
& & \\
\hline Strain 1 & IBDV_EGY2018/N44 & MH100980 \\
Strain 2 & IBDV_EGY2018/N23 & MH100981 \\
Strain 3 & IBDV_EGY2018/N46 & MH135301
\end{tabular}

The phylogenetic analysis of 3 IBDV strains shown in figure 3 demonstrated that strain 1 \& 2 clustered together with high relationship with previously isolated vvIBDV strains while strain three located away from them and clustered with the classical attenuated vaccinal strains Bursavac and CEVAC_IBDL.

Strain 1 and 2 showed high identity $97.5 \%$ between them, whereas strain 3 had lower identity $93.4-94.3 \%$ with them. In addition, the homology with the other vvIBDV strains; strain 1 showed (98.4\% and 98.8\%) homology with Egyptian vvIBDV strains Beh2003, Giza2000 and Giza2008 respectively, while strain 2 had $97.1 \%$ and $98.2 \%$ identity with the same strains. Furthermore, they also had similarities with foreign very virulent strains where strain 1 showed similarity $97.1 \%$ and $97.3 \%$ with Harbin-1 of china and UK_611 European like vvIBDV, respectively, and strain 2 had $96.7 \%$ and $98.2 \%$ homology with $\mathrm{SH}-\mathrm{h}$ of China and 26/92 of Poland. While strain 3 showed the highest homology $98.2 \%$ and $98.8 \%$ to Bursavac, HPR-2 and CEVAC_IBDL vaccinal strains and lower homology $95.7 \%$ with D78 and $95.3 \%$ with Bursine plus vaccines (table 2).

\subsection{Gross changes of molecular identified IBDV in ECE:}

The isolated vvIBDV strains on ECE resulted in $100 \%$ embryonic deaths from 48 hrs till five days PI and gross lesions were recorded on dead embryos and became pronounced with 3 succeeded passages as slight to moderate and severe congestion of embryos in different parts of the body especially head, breast and toe joint, cranial hemorrhage and liver congestion with necrotic foci (mottled appearance) besides, the greenish coloration of the liver. Moreover, renal and heart congestion were recorded. CAMs were thickened and had petechial hemorrhages (figure 4).

\subsection{Effect of different vaccination strategies on humoral immune response:}

From table 4 and figure 8, a non-significant difference was recorded in MDA ELISA titer in different groups until 21 days old. On the day of the challenge ( $25 \mathrm{~d})$, all vaccinated groups were significantly increased in Abs titer $(p>0.05)$ when compared with the $c$-ve group.

3.6. Effect of experimental infection with IBDV_EGY2018/N23 vvIBDV strain in broiler chicken in the following items: 


\subsubsection{Relative bursal weight:}

At 25 days of age, the $\mathrm{H}+\mathrm{I}$ and I vac. Groups reported a significant decrease $p>0.5$ in RWBF in comparison to the c-ve group while non- significant decrease was recorded in $\mathrm{H}$ vac. one while the c+ve, in addition to all vaccinated groups, showed a significant decrease $p>0.5$ in RWBF when compared with c-ve one at 5dPI. At ten dPI, a nonsignificant decrease in RWBF was recorded between different groups, as demonstrated in table 5 and figure 9.

\subsubsection{Cumulative bursal lesion scoring:}

At 25 days old: $\mathrm{H}$ and $\mathrm{H}+\mathrm{I}$ vac. groups showed a significant increase $(\mathrm{P}>0.5)$ in cumulative bursal score in comparison to cve group. At 5 and $10 \mathrm{dPI}$, the $\mathrm{c}+\mathrm{ve}$ challenged group recorded a significant increase $(\mathrm{P}>0.5)$ in cumulative bursal score than c-ve one. $\mathrm{H}$ and I vac. groups had a significant increase in the cumulative bursal score when compared with c-ve while the non-significant difference was recorded for $\mathrm{H}+\mathrm{I}$ vac. group at five dPI while all vaccinated groups showed a non-significant difference in comparison to the c-ve group at ten dPI (table 6 and figure 10).

\subsubsection{Mean Severity Index:}

After the experimental infection, $\mathrm{C}+\mathrm{ve}$ group recorded higher MSI than the c-ve group (0.9 at 5dPI, two at ten dPI). On the other hand, all vaccinated groups with different vaccinal strategies showed lower MSI than c+ve non vaccinated one and the $\mathrm{H}+\mathrm{I}$ vac. group recorded the lowest MSI; 0.2 at 5dPI, 0.5 at ten dPI (table 7 ).

\subsubsection{Histopathological findings of bursae of challenged broiler chicks:}

The control +ve group showed lymphoid depletion, necrosis cyst formation, and connective tissue proliferation (figure $5 \& 6$ ).

3.6.4. Molecularly detected IBDV from bursae of experimentally infected chicks:

The bursae of the c+ve group (nonvaccinated challenged) with vvIBDV strain isolate showed $620 \mathrm{bp}$ amplicon size ( figure $7)$.

Table (2): The identity \% between 3 sequenced strains and the reference ones:

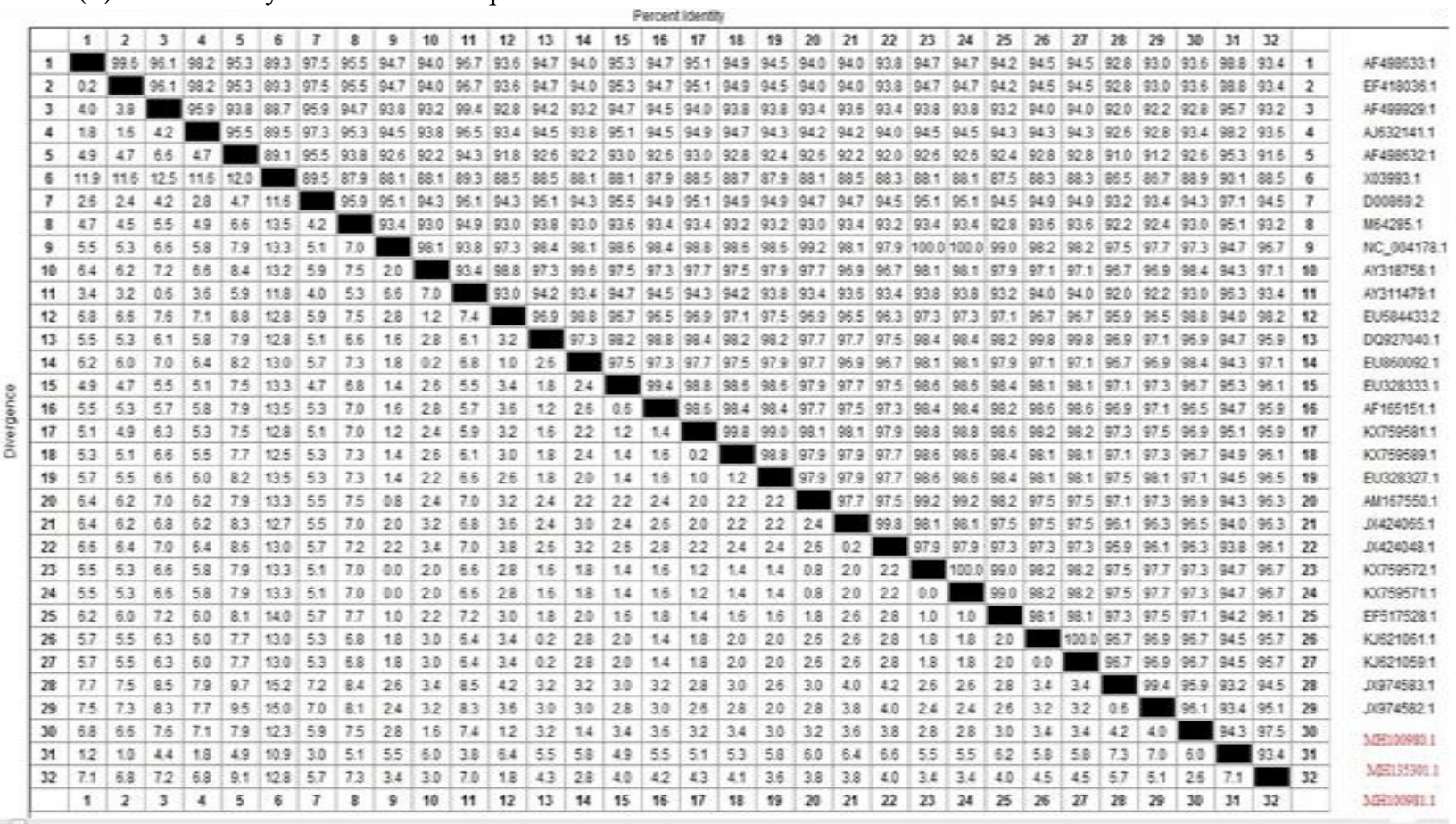


Epidemiological study on Infectious bursal disease in broiler chicken farms in some Governorates in Delta Egypt

Table (3): Experimental design.

\begin{tabular}{|c|c|c|c|c|c|c|}
\hline \multirow{2}{*}{$\begin{array}{l}\text { Group } \\
\text { No. }\end{array}$} & \multirow[t]{2}{*}{ Type of vaccine } & \multirow{2}{*}{$\begin{array}{l}\text { Vaccination age } \\
\text { / Route }\end{array}$} & \multirow{2}{*}{$\begin{array}{l}\text { Revaccination age/ } \\
\text { route }\end{array}$} & \multicolumn{3}{|l|}{ Experimental infection } \\
\hline & & & & strain & $\begin{array}{l}\text { Dose/ } \\
\text { route }\end{array}$ & Age \\
\hline G1 & - & - & - & - & - & - \\
\hline $\mathrm{G} 2$ & - & - & - & IBD_EGY2018/N23 & $\begin{array}{l}10^{5.5} \\
\text { EID50 } \\
\text { orally }\end{array}$ & $\begin{array}{l}25 d \\
\text { old }\end{array}$ \\
\hline G3 & $\begin{array}{l}\text { Hot HIPRA } \\
\text { GUMBORO } \\
\text { GM97 }\end{array}$ & $\begin{array}{l}12 \text { days old/ } \\
\text { ocular route }\end{array}$ & - & IBD_EGY2018/N23 & $\begin{array}{l}10^{5.5} \\
\text { EID50 } \\
\text { orally }\end{array}$ & $\begin{array}{l}25 d \\
\text { old }\end{array}$ \\
\hline G4 & $\begin{array}{c}\text { Intermediate } \\
\text { HIPRA } \\
\text { GUMBORO } \\
\text { CH80 }\end{array}$ & $\begin{array}{l}19 \text { days old/ } \\
\text { ocular route }\end{array}$ & - & IBD_EGY2018/N23 & $\begin{array}{l}10^{5.5} \\
\text { EID50 } \\
\text { orally }\end{array}$ & $\begin{array}{l}25 d \\
\text { old }\end{array}$ \\
\hline G5 & $\begin{array}{l}\text { Hot GM97+ } \\
\text { Intermediate } \\
\quad \text { CH80 }\end{array}$ & $\begin{array}{l}12 \text { days old by } \\
\text { hot vac. / ocular } \\
\text { route }\end{array}$ & $\begin{array}{l}19 \text { days old by } \\
\text { intermediate vac./ } \\
\text { ocular route }\end{array}$ & IBD_EGY2018/N23 & $\begin{array}{l}10^{5.5} \\
\text { EID50 } \\
\text { orally }\end{array}$ & $\begin{array}{l}25 d \\
\text { old }\end{array}$ \\
\hline
\end{tabular}

Table (4): ELISA antibodies titer for different vaccinated groups from zero to 25 days old.

\begin{tabular}{cllllll}
\hline Groups No & Groups & \multicolumn{1}{c}{ Zero $(d)$} & \multicolumn{1}{c}{$7(\mathrm{~d})$} & \multicolumn{1}{c}{$14(\mathrm{~d})$} & \multicolumn{1}{c}{$21(\mathrm{~d})$} & $25(\mathrm{~d})$ \\
\hline G1 & C-ve & $9526.3^{\mathrm{a}} \pm 262.19$ & $5081.0^{\mathrm{a}} \pm 385.84$ & $2472.3^{\mathrm{a}} \pm 394.88$ & $842.67^{\mathrm{a}} \pm 177.13$ & $96.33^{\mathrm{c}} \pm 22.30$ \\
G2 & C+ve & $8702^{\mathrm{a}} \pm 377.72$ & $4470.0^{\mathrm{a}} \pm 380.00$ & $1835.0^{\mathrm{a}} \pm 167.50$ & $853.33^{\mathrm{a}} \pm 177.42$ & $198^{\mathrm{bc}} \pm 87.23$ \\
G3 & H vac. & $8323.3^{\mathrm{a}} \pm 101.68$ & $4265.3^{\mathrm{a}} \pm 569.78$ & $2248.0^{\mathrm{a}} \pm 318.53$ & $1390.0^{\mathrm{a}} \pm 194.56$ & $813^{\mathrm{a}} \pm 128$ \\
G4 & I vac. & $8583.1^{\mathrm{a}} \pm 106.56$ & $5030.7^{\mathrm{a}} \pm 747.76$ & $2102.0^{\mathrm{a}} \pm 401.86$ & $1021.7^{\mathrm{a}} \pm 260.03$ & $599^{\mathrm{ab}} \pm 263$ \\
G5 & H+I vac. & $8024.3^{\mathrm{a}} \pm 661.89$ & $389.8 .0^{\mathrm{a}} \pm 315.07$ & $2078.3^{\mathrm{a}} \pm 327.95$ & $865.67^{\mathrm{a}} \pm 146.75$ & $647^{\mathrm{ab} \pm 118}$ \\
\hline
\end{tabular}

Each value represented the mean \pm standard error .Values with different letters within the same column are significantly different $(\mathrm{p}<0.5)$.

$\mathrm{C}$-ve: non vaccinated non challenged, c+ve: non-vaccinated challenged, $\mathrm{H}$ : hot vaccinated, I: intermediate vaccinated groups.

Table (5): Relative bursal weight recordings in challenged broiler chicks with 105.5 EID50 of vvIBDV isolate before challenge and 5,10 dPI:

\begin{tabular}{lllll}
\hline & & Before challenge & \multicolumn{2}{c}{ After challenge } \\
\cline { 4 - 4 } Groups No & Groups & 25 days old & $5 \mathrm{dPI}$ & $10 \mathrm{dPI}$ \\
\hline G1 & & $0.17^{\mathrm{a}} \pm 0.03$ & $0.19^{\mathrm{a}} \pm 0.01$ & $0.16^{\mathrm{a}} \pm 0.02$ \\
G2 & C-ve & $0.12^{\mathrm{ab}} \pm 0.02$ & $0.10^{\mathrm{b}} \pm 0.02$ & $0.11^{\mathrm{a}} \pm 0.04$ \\
G3 & C+ve & $0.11^{\mathrm{abc}} \pm 0.02$ & $0.11^{\mathrm{b}} \pm 0.01$ & $0.11^{\mathrm{a}} \pm 0.04$ \\
G4 & H vac. & $0.08^{\mathrm{bc}} \pm 0.01$ & $0.05^{\mathrm{b}} \pm 0.01$ & $0.08^{\mathrm{a}} \pm 0.01$ \\
G5 & I vac. & $0.05^{\mathrm{c}} \pm 0.01$ & $0.11^{\mathrm{b}} \pm 0.04$ & $0.12^{\mathrm{a}} \pm 0.02$
\end{tabular}

Each value represented the mean \pm standard error .Values with different letters within the same column are significantly different $(\mathrm{p}<0.5)$.C-ve: non vaccinated non challenged, $\mathrm{c}+\mathrm{ve}$ : non-vaccinated challenged, $\mathrm{H}$ : hot vaccinated, I: intermediate vaccinated groups. 
Table (6): Cumulative bursal scoring recordings of challenged broiler chicks with 105.5 EID50 of vvIBDV isolate before challenge and 5, $10 \mathrm{dPI}$ :

\begin{tabular}{|c|c|c|c|c|}
\hline \multirow[t]{2}{*}{ Groups No } & \multirow[t]{2}{*}{ Groups } & \multirow{2}{*}{$\begin{array}{l}\text { Before challenge } \\
25 \text { days old }\end{array}$} & \multicolumn{2}{|c|}{ After challenge } \\
\hline & & & $5 \mathrm{dPI}$ & 10dPI \\
\hline G1 & C-ve & $0.00^{\mathrm{c}} \pm 0.00$ & $0.00^{\mathrm{b}} \pm 0.00$ & $0.00^{\mathrm{b}} \pm 0.00$ \\
\hline G2 & $\mathrm{C}+\mathrm{ve}$ & $0.00^{\mathrm{c}} \pm 0.00$ & $6.33^{\mathrm{a}} \pm 1.45$ & $13.67^{a} \pm 5.23$ \\
\hline G3 & $\mathrm{H}$ vac. & $1.33^{\mathrm{b}} \pm 0.33$ & $5.67^{\mathrm{a}} \pm 1.86$ & $4.67^{\mathrm{b}} \pm 1.41$ \\
\hline G4 & I vac. & $0.67^{b c} \pm 0.33$ & $5.00^{\mathrm{a}} \pm 2.00$ & $5.00^{\mathrm{b}} \pm 2.00$ \\
\hline G5 & $\mathrm{H}+\mathrm{I}$ vac. & $4.67^{\mathrm{a}} \pm 0.67$ & $2.67^{\mathrm{ab}} \pm 0.67$ & $3.33^{\mathrm{b}} \pm 0.33$ \\
\hline
\end{tabular}

Each value represented the mean \pm standard error .Values with different letters within the same column are significantly different $(\mathrm{p}<0.5)$. C-ve: non vaccinated non challenged, $c+v e$ : non-vaccinated challenged, $\mathrm{H}$ : hot vaccinated, I: intermediate vaccinated groups.

Table (7): Mean severity index recordings of challenged broiler chicks with 105.5 EID50 of vvIBDV isolate before challenge and 5, $10 \mathrm{dPI}$ :

\begin{tabular}{cccc}
\hline Group & Depletion & Necrosis & MSI \\
\hline C-ve 25 d & 0 & 0 & 0 \\
C+ve 25 d & 0 & 0 & 0 \\
H 25d & 1.3 & 0 & 0.7 \\
I 25d & 1 & 0 & 0.5 \\
HI 25d & 1.6 & 0 & 0.8 \\
C-ve 5 dPI & 0 & 0 & 0 \\
C+ve 5 dPI & 1.7 & 0 & 0.9 \\
H 5dPI & 1 & 0 & 0.5 \\
I 5dPI & 1 & 0 & 0.5 \\
HI 5dPI & 1.7 & 0 & 0.2 \\
C-ve 10 dPI & 0 & 0 & 0 \\
C+ve 10 dPI & 2 & 2 & 2 \\
H 10dPI & 1.3 & 0 & 0.7 \\
I 10dPI & 1.3 & 1 & 1.2 \\
HI 10DPI & 1 & 0 & 0.5 \\
\hline
\end{tabular}

0: normal $\quad$ 1: mild lesion $\quad$ 2: moderate lesion $\quad 3$ : severe lesions

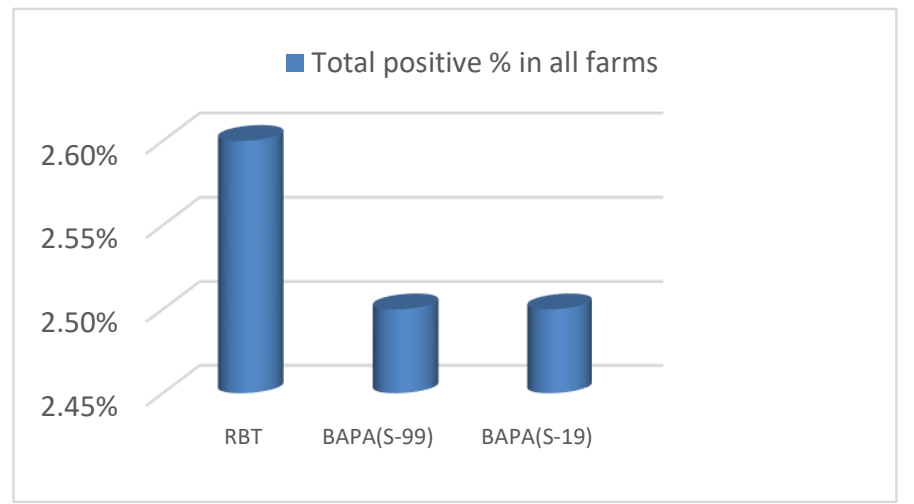

Figure (1): A- whitish and yellowish diarrhea. Bpetecheal hemorrhage on thigh, breast muscles. CHemorrhagic bursitis. D- Caseous bursitis.amplicon size.

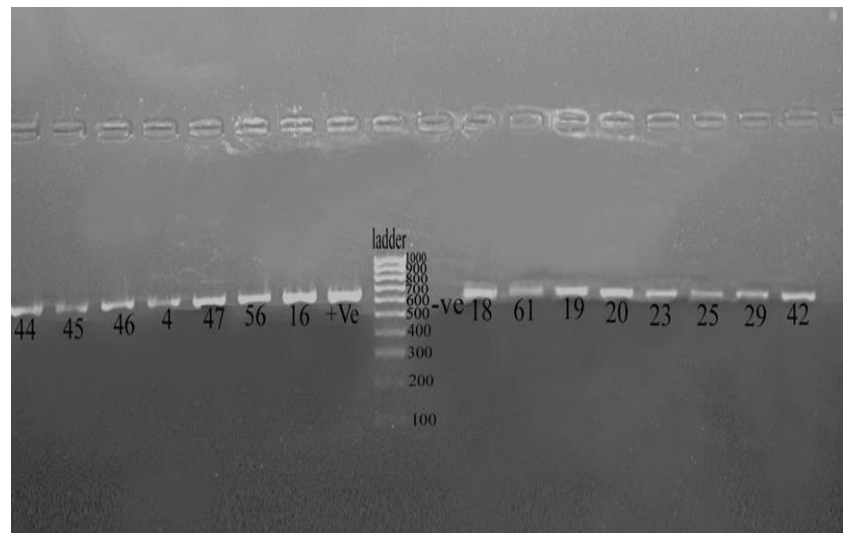

Figure (2): Agarose gel electrophoresis showed the positive amplified PCR products. The size of +ve product (620 bp). + ve control positive. -ve control negative. 
Epidemiological study on Infectious bursal disease in broiler chicken farms in some Governorates in Delta Egypt

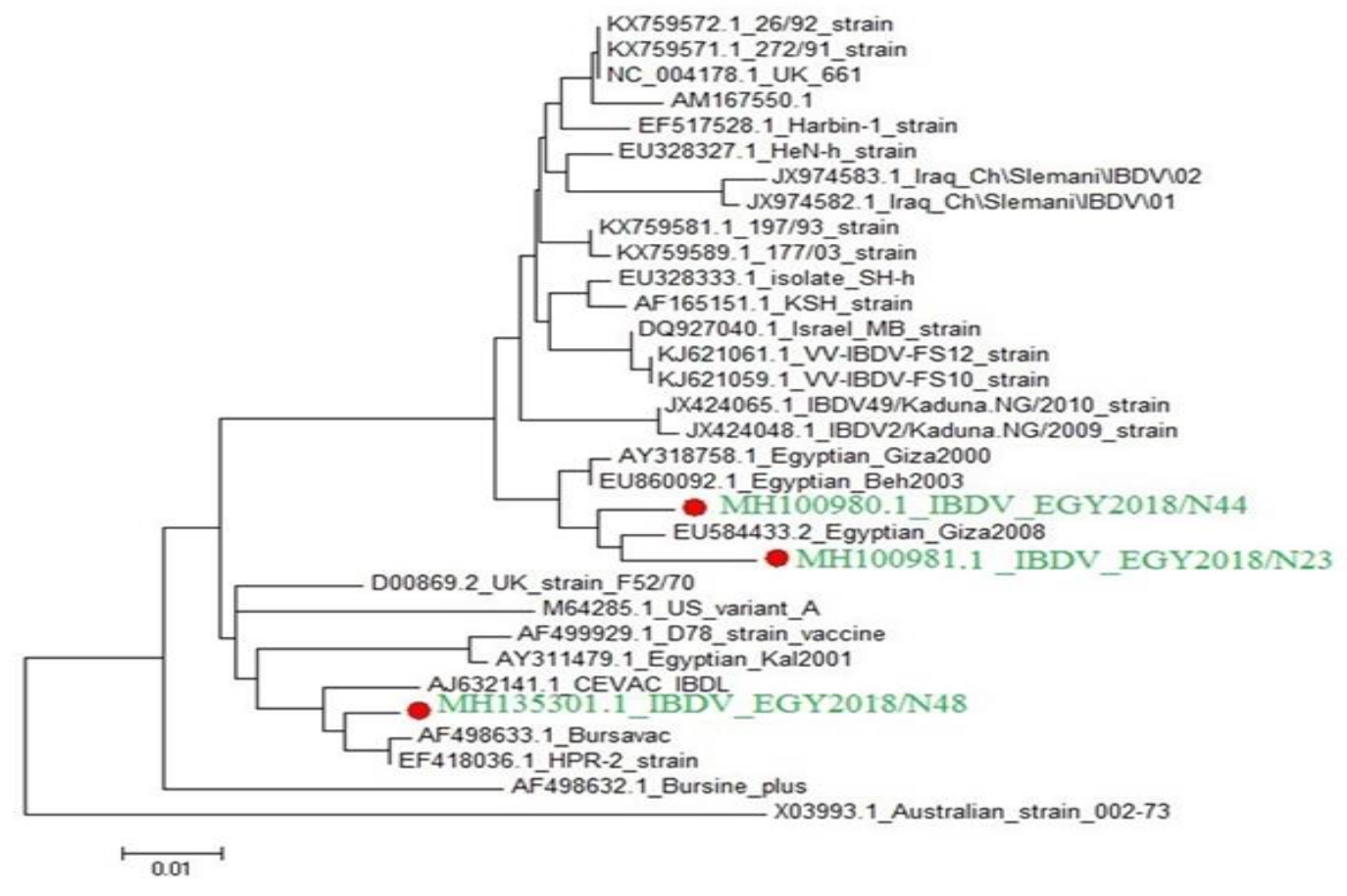

Figure (3): The phylogenetic analysis of the three sequenced strains.

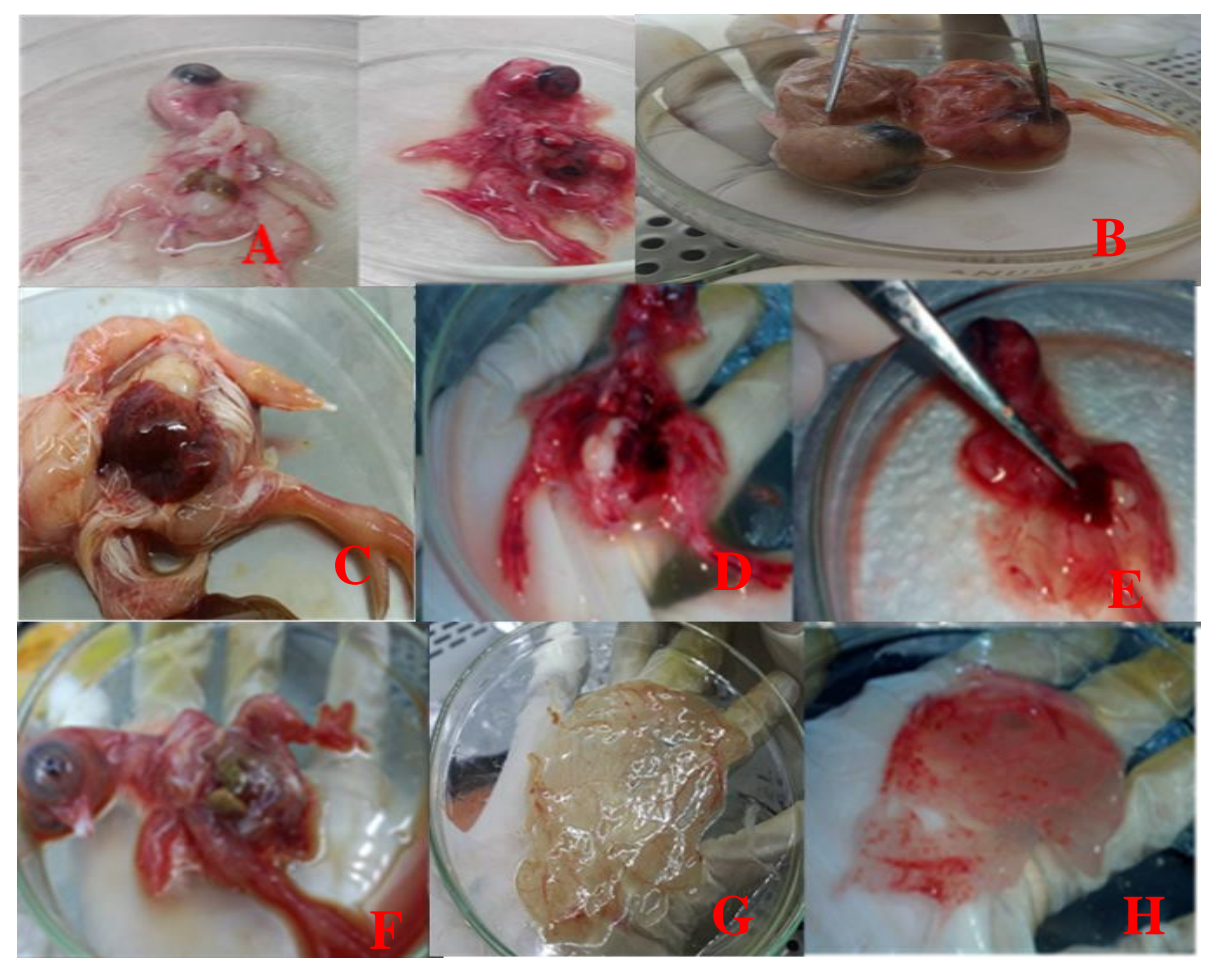

Figure (4): A-congestion of inoculated embryo body (L) compared to non-inoculated control one (R). BCranial hemorrhage of inoculated embryo. C- Congestion with necrotic foci of embryo liver. D- Severe renal congestion. E- Embryo hepatic congestion. F- Greenish coloration of liver. G- Thickened CAMs. HPetechial hemorrhages on CAMs. 


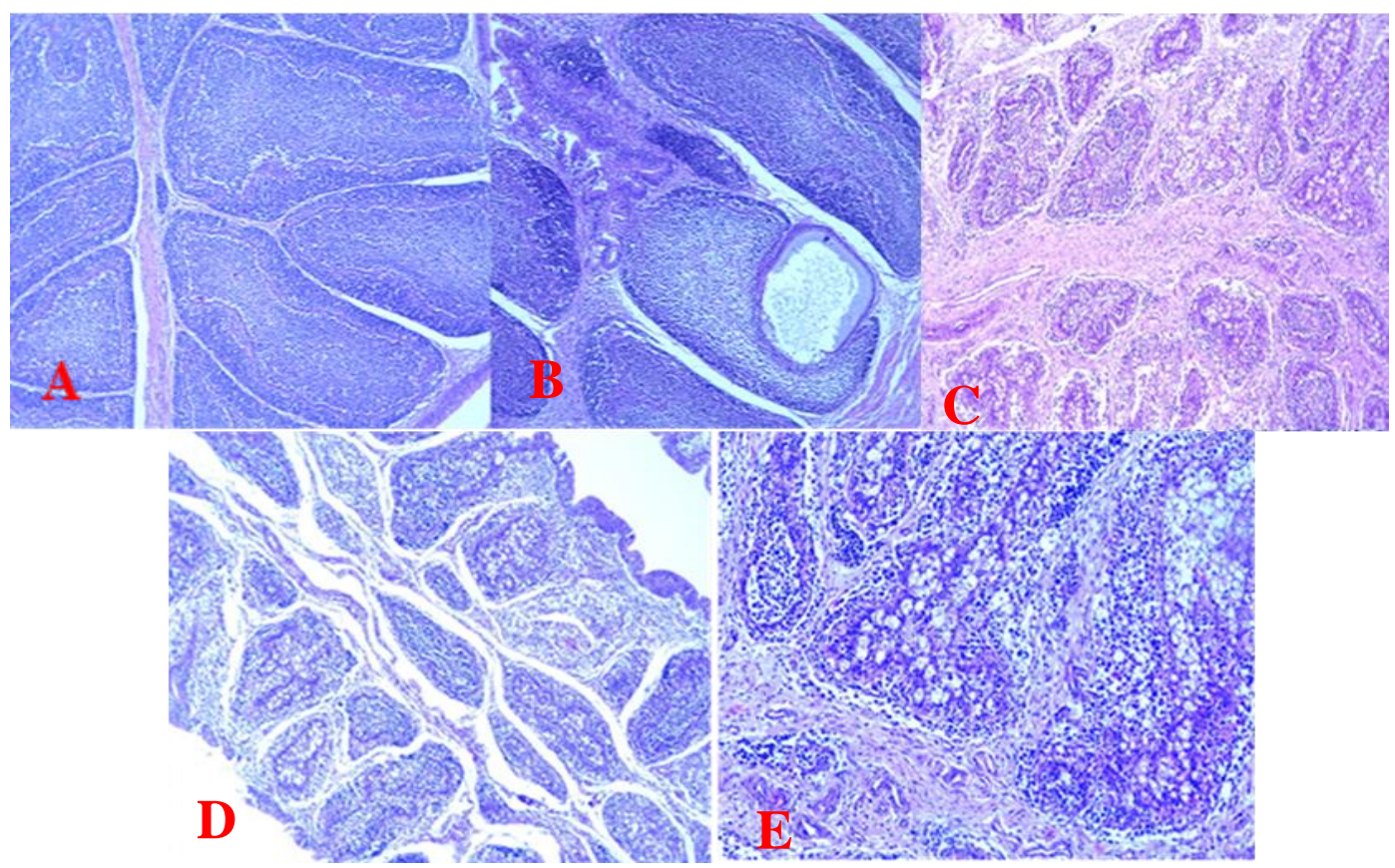

Figure (5) A- Bursa of c-ve group with apparently normal architecture (H\&EX100). B- Bursa of c+ve group at 5dPI with depletion of lymphocyte of medulla of lymphoid follicle with cyst formation and epithelization. c- Bursa of c+ve group at $10 \mathrm{dPI}$ with corrugated hyperplasia of lining epithelium and interfollicular connective tissue proliferation (H\&E X200). D- Bursa of c+ve group at $10 \mathrm{dPI}$ and interfollicular edema and depletion of lymphoid follicle. E- Bursa of c+ve group at $10 \mathrm{dPI}$ with microcyst formation (H\&E X100).

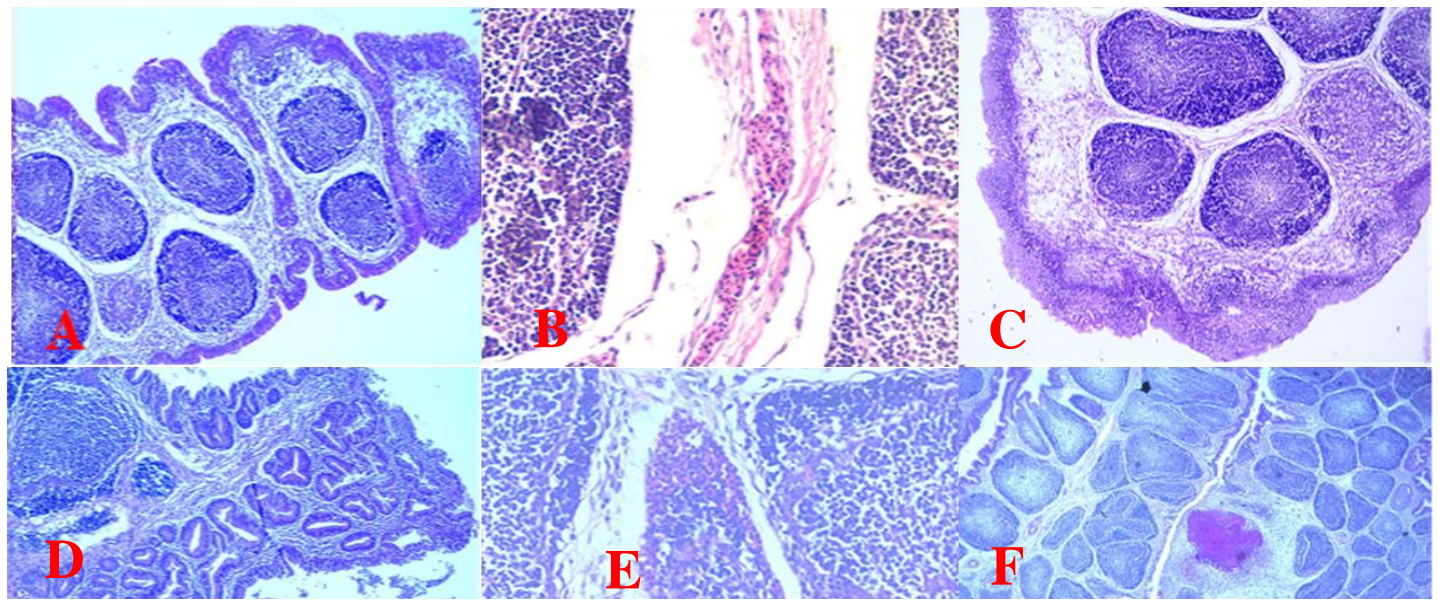

Figure (6): A- Bursa of hot vac. group at $5 \mathrm{dPI}$ with corrugated hyperplasia of lining epithelium and interfollicular edema with inflammatory cell infiltration (H\&E X200). B- Bursa of hot vac. group at $10 \mathrm{dPI}$ with interfollicular congestion (H\&E X400). C- Bursa of hot + intermediate vac. group at $5 \mathrm{dPI}$ with hyperplasia and metaplasia of lining epithelium with interfollicular edema, depletion and degeneration of lymphocytes (H\&E X200). D- Bursa of hot + intermediate vac. group at $10 \mathrm{dPI}$ with connective tissue proliferation and epithelization (H\&E X100. EBursa of intermediate vac. group at $5 \mathrm{dPI}$ with proliferation of granulocytes (H\&E X400). F- Bursa of intermediate vac. group at $10 \mathrm{dPI}$ with depletion of lymphocytes, interfollicular edema and multiple suppurative areas composed of central necrotic tissue surrounded by heterophils and epithelioid macrophages (H\&E X100). 


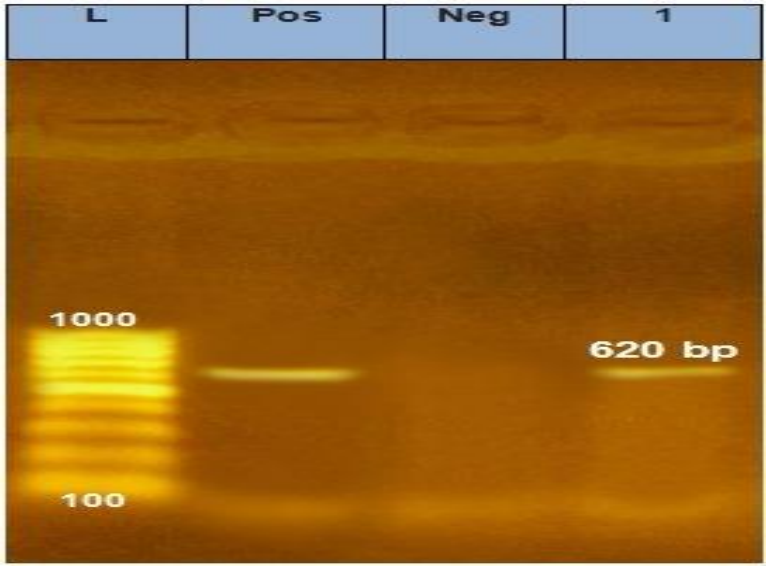

Figure (7): Gel electrophoresis of PCR product of positively infected bursae of control +ve group that showed 620 bp amplicon size.

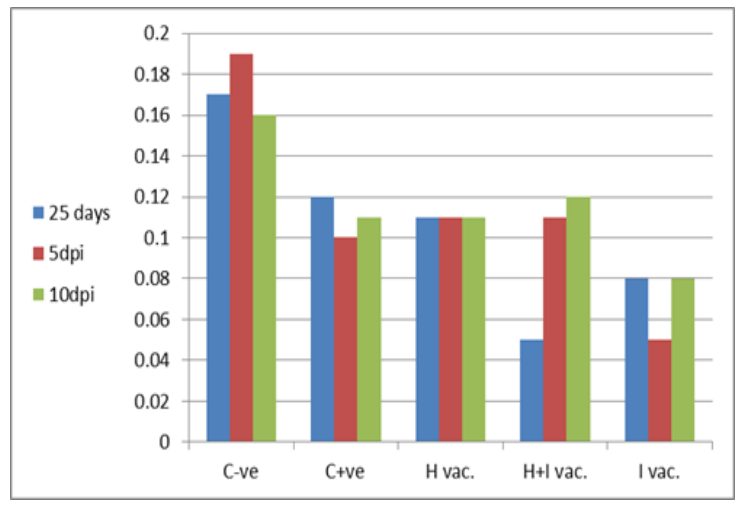

Figure (9): Chart showed relative bursal weight (RWBF).

\section{DISCUSION}

Infectious bursal disease is a highly contagious disease that became a severe problem in Egypt as it recurred in successive rounds and became endemic as a result of the nature of IBDV as a highly resistant virus (Metwally et al., 2003; Maclachlan and Dubovi, 2010).

The clinical diagnosis of suspected cases depended on clinical signs and P.M. examination of IBD suspected cases where

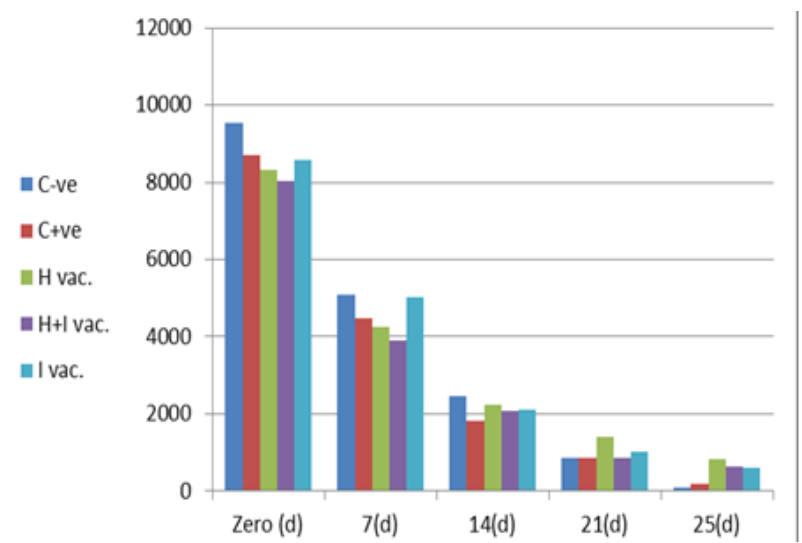

Figure (8): Chart showed ELISA antibody titers.

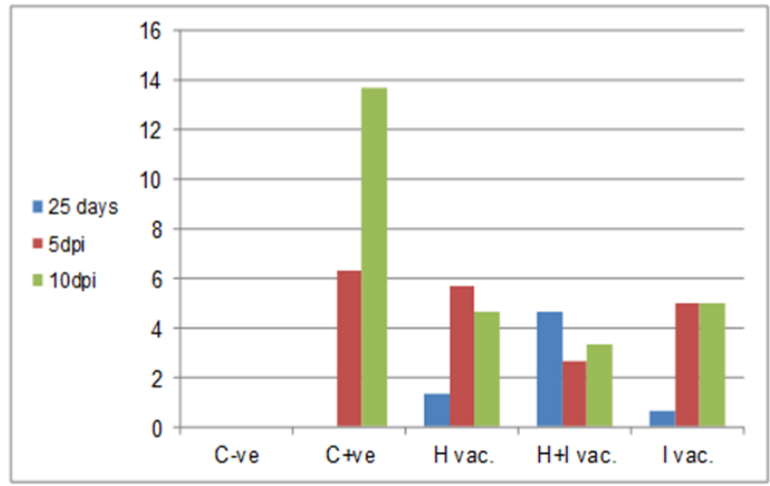

Figure (10): Chart of cumulative bursal lesion scoring.

we found pasty vents with whitish and yellowish diarrhea externally. On internal P.M examination, mild to severe enlarged, congested, hemorrhagic and gelatinous bursae with caseated material, nephrosis kidney with distended ureter with urates and petechial hemorrhage in breast and thigh muscles which were supported by earlier reports of Quinn and Jesús, (2003); Quinn et al., (2011).

Regarding the molecular prevalence of IBD, 15 out of a total of 32 samples were positive 
IBDV $(46.8 \%)$. This result was more or less similar to those described by Abdel-Alim et al., (2003); El-shall et al., (2018) in contrast to results recorded by Mittal et al., (2006) who reported a higher incidence of IBD,

where 17 out of 20 total samples $(85 \%)$ collected from Haryana state in India. Differences in prevalence may be attributed to differences in locality breed and age susceptibility.

Nucleotide sequencing of the hyper-variable region of VP2, giving the most informative genetic data regarding strain variability to characterize IBDV strains (Banda et al., 2003). Concerning to our results, two of our strains were classified as vvIBDV as they clustered close to previously identified Egyptian vvIBDVs Giza 2000 and Giza 2008 with high identity $97.1 \%-98.8 \%$. That came in accordance with Shehata et al., (2017). Furthermore, they recorded high identity ranged from $96.7 \%$ to $98.2 \%$ with UK_611 European like vvIBDV that was similar to reports of Paula et al., (2004). Dissimilarly to records of El-Bagoury et al., (2015) where IBDV-Giza 2014 characterized as variant having only $89.8 \%$ identity with Egyptian vvIBDV. As for the third strain in this study, it showed the highest homology showed high identity $98.2 \%$ and $98.8 \%$ to Bursavac and CEVAC_IBDL vaccinal strains and this agreed with Mawgod et al., (2014). This may be due to the continuous mutation of IBDV which affects the virus antigenicity and virulence leading to emergence of vvIBDVs strains and the presence of vaccinal strain may indicates circulation of live vaccinal viruses due to the irregular vaccination programs (Van den Berg et al., 2004).

Regarding our results of isolation on SPF eggs, our isolates caused $100 \%$ embryo mortalities within $72 \mathrm{hrs}$ in the first passage and $48 \mathrm{hrs}$ within a second and third passage with moderate to severe embryos congestion in different parts of the body, cranial hemorrhage and liver congestion with greenish necrotic liver and CAMs showed thickening and petechial hemorrhage that agreed with Shehata et al., (2017).
Dissimilarly, greenish dwarfing embryo, splenomegaly and cerebral edema for variant IBDV were recorded by Amer et al., (2007). The pathogenicity test with IBDV resulted in a significant decrease ( $p>0.05)$ in RWBF and histopathological lesion score in comparison with $\mathrm{c}-\mathrm{ve}$ one at $5,10 \mathrm{~d}$ PI that came in accordance with Kurukulasuriya et al. , (2017).

All the vaccination strategies succeeded to induce the humoral immunity and gave $\mathrm{Ab}$ titers which were significantly increased $p>0.05$ in comparison with the nonvaccinated group at 25 days old (day of the challenge) but the hot strain GM97 gave the highest titer that agreed with reports of Nishizawa et al., (2007). Dissimilarly, Rautenschlein et al., (2005) found that only intermediate plus induced significant ELISA antibody titer in comparison with nonvaccinated at $21 \mathrm{~d} \mathrm{P}$.V while intermediate did not. They also showed a non-significant difference in RWBF and cumulative bursal lesion score in comparison to c-ve one at ten dPI and lower MSI than c+ve but the hot + intermediate vac. group recorded the lowest cumulative lesion score and MSI that came in disagreement with Sarachai et al., (2010) who recorded non-significant difference between vaccinated and non-vaccinated groups at 30 days (before challenge) in RWBF and between challenged and vaccinated at $10 \mathrm{~d}$ PI. The efficacy of the IBD vaccination program was related to the level of MDA in the chickens at the age of vaccination that interferes with the ability of the vaccinal virus to stimulate the immunity of the host. Hot strains can break through a high level of MDA and stimulate humoral immunity, but it causes severe bursal lesion and lymphoid depletion in contrast to the intermediate strains that have a moderate lymphoid depletion effect (Eterradossi and Saif 2008).

This study concluded that the prevalence of IBD among broiler chicken farms in different localities of some Delta governorates during 2016-2017 was $46.87 \%$, and the presence of very virulent strains occurs as a result of antigenic mutation. In addition, the used vaccination strategies did not induce $100 \%$ 
protection against vvIBDV that makes other vaccination strategies investigation is a must.

\section{REFERANCES}

Abdel-Alim, G. A., Awaad, M. H. H. and Saif, Y. (2003): Characterization of Egyptian field strains of infectious bursal disease virus. Avian diseases 47(4): 1452-1457.

Amer, M., El-Bayomi, K., Kotkat, M., ElGhany, W. A. A., Shakal, M. and ElGaid, S. S. A. (2007): Isolation, molecular characterization and pathogenicity studies of infectious bursal disease field virus isolates. The 5th Scientific Conference of the Faculty of Veterinary Medicine, BeniSuef University November 6 th-9th.

Atkinson, G. (1961): The Spearman-Karber Method of Estimating 50\% Endpoints.

Banchroft, J.D. , Stevens, A. and Turner, D.R. (1996): Theory and practice of histological techniques.Fourth Ed. Churchil Livingstone, New York, London, San Francisco, Tokyo.

Banda, A., Villegas, P. and El-Attrache, J. (2003): Molecular characterization of infectious bursal disease virus from commercial poultry in the United States and Latin America. Avian diseases 47(1): 87-95.

Bayliss, C., Spies, U., Shaw, K., Peters, R., Papageorgiou, A., Müller, H. and Boursnell, M. (1990): A comparison of the sequences of segment $\mathrm{A}$ of four infectious bursal disease virus strains and identification of a variable region in VP2. Journal of General Virology 71(6): 1303-1312.

Buitkamp, J., Ammer, H. and Geldermann, H. (1991): DNA fingerprinting in domestic animals. Electrophoresis 12(2-3): 169-174
Duncan, D. B. (1955): Multiple range and multiple F tests. Biometrics, 11(1), 142.

Durairaj, V., Sellers, H. S., Linnemann, E. G., Icard, A. H., and Mundt, E. (2011): Investigation of the antigenic evolution of field isolates using the reverse genetics system of infectious bursal disease virus (IBDV). Archives of Virology, 156(10): 1717-1728.

El-Bagoury, G., Nada, A., El-Habbaa, A. and Abu-Zied, A. (2015): Molecular characterization of IBD virus isolated from Giza governorate, Egypt Benha Veterinary Medical Journal, 28(1):223-234

El-shall, N. A., Sedeek, M. E., El-badawy, M. M., Hussein, E. G. and Awad, A. M. (2018): Phylogenetic Characterization of Infectious Bursal Disease (IBD) Viruses Isolated From Field Outbreaks in Chickens From Behera And Alexandria Governorates, Egypt. Alexandria Journal for Veterinary Sciences 56(1).

Eterradossi, N. and Saif, Y. (2008): Infectious bursal disease. Diseases of poultry 12 th edition: $185-208$.

Fauquet, C. M., Mayo, M. A., Maniloff, J., Desselberger, U., \& Ball, L. A. (2005): Virus taxonomy: VIIIth report of the International Committee on Taxonomy of Viruses: Academic Press.

Hussain, Z. (2006): Aflatoxicosis in chicken: an inter-relationship between pathology, dietary and tissue aflatoxin levels. PhD degree thesis, Faculty of Veterinary Science, University of Agriculture, Faisalabad, Pakistan.

Kurukulasuriya, S., Ahmed, K. A., Ojkic, D., Gunawardana, T., Goonewardene, K., Gupta, A., Chow-Lockerbie, B., Popowich, S., Willson, P. and Tikoo, S. K. (2017): Modified live infectious 
bursal disease virus (IBDV) vaccine delays infection of neonatal broiler chickens with variant IBDV compared to turkey herpesvirus (HVT)-IBDV vectored vaccine. Vaccine 35(6): 882 888.

Maclachlan, N. J. and Dubovi , E. J. (2010): Fenner's veterinary virology, Academic press.

Mawgod, S. A., Arafa, A. S. and Hussein, H. A. (2014): Molecular genotyping of the infectious bursal disease virus (IBDV) isolated from Broiler Flocks in Egypt. International Journal of Veterinary Science and Medicine 2(1): 46-52.

Metwally, A. , Sabry, M., Samy, A., Omar, M., Yousif, A. and Reda, I. (2003): Direct detection of variant infectious bursal disease virus in vaccinated Egyptian broiler flocks using antigencapture ELISA. Veterinary Medical Journal Giza 51(1): 105-119.

Mittal, D., Jindal, N., Gupta, S. L., Kataria, R. S., Singh, K. and Tiwari, A. K. (2006): Molecular characterization of Indian isolates of infectious bursal disease virus from broiler chickens: full Length Research Paper. DNA sequence 17(6): 431-439.

Nishizawa, M., Paulillo, A., Bernardino, A., Alessi, A., Sayd, S., Okada, L. and Junior, L. D. (2007): Evaluation of anatomopathological, serological, immunological responses and protection in broilers vaccinated with live infectious bursal disease vaccines. Arquivos do Instituto Biologico, Sao Paulo 74(3): 219-226.

OIE, Terrestrial Manual (2016): Infectious bursal disease (Gumboro disease). Manual of Diagnostic Tests and Vaccines for Terrestrial Animal. Chapter 2.3.12.
Paula, M. B. C. d., Yokosawa, J., Coutinho, M. D. B., Silva, P. L., Ferraz, R. A., Oliveira, T. F. M. and Queiróz, D. A. O. (2004): Identification and molecular characterization of the infectious bursal disease virus (IBDV) from an outbreak in a broiler flock in midwestern Brazil. Brazilian Journal of Microbiology 35(4): 352-358.

Quinn, P. J. and Jesús, M. (2003): Elementos de microbiologia veterinaria/Concise review of veterinary microbiology.

Quinn, P. J., Markey, B. K., Leonard, F. C., Hartigan, P., Fanning, S. and FitzPatrick, E. (2011): Veterinary microbiology and microbial disease, John Wiley \& Sons.

Rautenschlein, S., Kraemer, C., Vanmarcke, J. and Montiel, E. (2005): Protective efficacy of intermediate and intermediate plus infectious bursal disease virus (IBDV) vaccines against very virulent IBDV in commercial broilers." Avian diseases 49(2): 231237.

Sarachai, C., Chansiripornchai, N. and Sasipreeyajan, J. (2010): Efficacy of infectious bursal disease vaccine in broiler chickens receiving different vaccination programs. The Thai Journal of Veterinary Medicine 40(1): 9-14.

Sharma, J., Dohms, J. and Metz, A. (1989): Comparative pathogenesis of serotype 1 and variant serotype 1 isolates of infectious bursal disease virus and their effect on humoral and cellular immune competence of specificpathogen-free chickens. Avian diseases: 112-124.

Shehata, A. A., Sultan, H., Halami, M. Y., Talaat, S. and Vahlenkamp, T. W. (2017): Molecular characterization of very virulent infectious bursal disease virus strains circulating in Egypt from 
2003 to 2014. Archives of Virology: 113.

Snyder, D., Vakharia, V., and Savage, P. (1992): Naturally occurringneutralizing monoclonal antibody escape variants define the epidemiology of infectious bursal disease viruses in the United States. Archives of Virology, 127(1), 89-101.

Stoute, S. T., Jackwood, D. J., SommerWagner, S. E., Crossley, B. M., Woolcock, P. R. and Charlton, B. R. (2013): Pathogenicity associated with coinfection with very virulent infectious bursal disease and Infectious bursal disease virus strains endemic in the United States. Journal of Veterinary Diagnostic Investigation 25(3): 352-358.

Tamura, K., Stecher, G., Peterson, D., Filipski, A. and Kumar, S. (2013): MEGA6: molecular evolutionary genetics analysis version 6.0. Molecular biology and evolution 30(12): 2725-2729.

Tanimura, N., Tsukamoto, K., Nakamura, K., Narita, M. and Maeda, M. (1995): Association between pathogenicity of infectious bursal disease virus and viral antigen distribution detected by immunohistochemistry. Avian diseases 39(1): 9-20.

Teshome, M., Fentahunand, T., and Admassu, B. (2015): Infectious bursal disease (Gumboro disease) in Chickens. British Journal of Poultry Sciences, 4(1), 22-28.
Thompson, J. D., Higgins, D. G. and Gibson, T. J. (1994): CLUSTAL W: improving the sensitivity of progressive multiple sequence alignment through sequence weighting, position-specific gap penalties and weight matrix choice. Nucleic acids research 22(22): 46734680 .

Van den Berg, T., Morales, D., Eterradossi, N., Rivallan, G., Toquin, D., Raue, R., Zierenberg, K., Zhang, M., Zhu, Y. and C. Wang (2004): Assessment of genetic, antigenic and pathotypic criteria for the characterization of IBDV strains. Avian Pathology 33(5): 470-476

.Wang, Y., Sun, H., Shen, P., Zhang, X., Xia, X., \& Xia, B. (2010): Effective inhibition of replication of infectious bursal disease virus by miRNAs delivered by vectors and targeting the VP2 gene. Journal of virological methods, 165(2), 127-132.

Withers, D. R., Young, J. R., and Davison, T. F. (2005): Infectious bursal disease virus-induced immunosuppression in the chick is associated with the presence of undifferentiated follicles in the recovering bursa. Viral immunology, 18(1), 127-137.

Xu, X. G., Tong, D. W., Wang, Z. S., Zhang, Q., Li, Z. C., Zhang, K., Liu, H. J. (2011): Baculovirus virions displaying infectious bursal disease virus VP2 protein protect chickens against infectious bursal disease virus infection. Avian diseases, 55(2), 223229. 